af de to. Han forlader modsætning og bekender sig som en god liberal pragmatist. Og det er ganske befriende. Så han slutter med at gøre både rationalisten og anti-rationalisten til pragmatister.

Musikken står Kirsten Sass Bak for. Hun er ganske kontant. Om musikken har med almendannelse at gøre kan kun besvares "empirisk", siger hun. Hun fortæller i forlængelse heraf om den rolle som musikken har spillet $i$ kulturen og uddannelsessystemet. Som en af de få i antologien taler Kirsten Bak om, at musikalsk dannelse har at gøre med en bestemt musiksmag: "den gode!"

På bagsiden af bogen står der, at den giver mange bud på, hvad dannelse kan være, for det definitive svar findes sandsynligvis ikke. Det kan være sandt nok, men man kan lære af Kirsten Sass Bak. Man kan svare empirisk. Hvor findes svaret? I loven og det vil sige $\mathrm{i}$ Tid til forandring for Danmarks universiteter udsendt af regeringen uden støtte fra Dansk og Socialistisk Folkeparti. Og i den nævnes ordet dannelse ikke. Det er dannelse i virkeligheden.

Hans Hange

\section{Smagfuld gryderet}

Lars Fr. H. Svendsen, Ondskabens filosofi, oversat af Joakim Wrang, Forlaget Klim, Arbus 2002, 223 s., 245 kr.

Hvad er ondskab idéhistorisk betragtet, hvilke former for ondskab står vi overfor i dag, og hvad skal man gøre ved den? Det er ikke mindst spørgsmål som disse, der rejses og forsøges besvaret i Lars Fr. Svendsens nye udgivelse Ondskabens filosofi. Bogen består af forord, indledning, samt tre hovedafsnit. Først behandles det onde i første hovedafsnit, Ondskabens teologi, i et idéhistorisk perspektiv og med udgangspunkt $i$ theodicé-problemet, hvorefter den i andet afsnit, Ondskabens antropologi, inddeles $i$ fire overordnede typologier. Dette peger igen frem mod bogens egentlige hovedbudskab eller tema, nemlig sidste afsnits (Ondskabens problem) aktualisering af det onde ud fra en praktisk synsvinkel. Bogen slutter med et efterord og en epilog, hvor der knyttes an til begivenhederne omkring 11. september 2001. Derudover er der et udførligt appendiks i form af ikke mindre end 742 noter (!).

Resumé: I forordet til Ondskabens filosofi tager forfatteren afstand fra tidens æstetisering af det onde, idet han her henviser til sit eget tidligere værk om Kedsomhedens Filosofi. Den omsiggribende æstetisering er et problem, hævdes det, i stedet grelder det om at tage det onde alvor- 
ligt “..som et moralsk objekt, og en forståelse af det onde er afgørende for at komme til en forståelse af os selv og de forpligtigelser, vi har overfor andre mennesker" (s.7f.). En af grundtankerne i bogen bringes således allerede her på bane, nemlig at fokus mere rettes mod det onde som det udøves af almindelige mennesker, frem for at have sit udspring i dæmonien hos såkaldte monstre, seriemordere mv. På grund af emnets omfattende karakter tages der dog allerede her flg. forbehold: "Det ville være et intellektuelt overmod at tro, at jeg kunne gøre ondskaben fuldt ud forståelig" (s.9).

"Hvad er det onde, og hvordan kan det forstås?", spørges der herefter i værkets indledning. At dette spørgsmål overhovedet kan besvares fyldestgørende, afvises med det samme som essentialisme, idet der $i$ stedet knyttes an til en fænomenologisk tilgang, der intentionelt forbliver på overfladen frem for at gå i dybden. "Min hovedpointe i denne bog er meget enkel; Det onde er ikke først og fremmest et teoretisk, men et praktisk problem. Spørgsmålet om, hvordan det onde kom ind i verden, om det har sin egen væren eller bare er at forstå som en mangel osv., er mindre vigtigt end spørgsmålet om, hvordan det kan forhindres" (s.22). Dødstallene for det tyvende århundredes krige, Holocaust mv. opregnes her $i$ en længere gennemgang af historiske fakta, som forfatteren udviser et indgående kendskab til.
Som allerede nævnt behandles i det første hovedafsnit teodicé-problemet i et idéhistorisk perspektiv. Lars Fr. Svendsen lægger her ud med en etymologisk og historisk redegørelse for teodicé-problemet. Der henvises udførligt, bl.a til Leibniz, Platon, Plotin, Augustin, Dostojevski, Thomas Aquinas og ikke mindst til bibelen. På relativt overskuelig vis skelnes der mellem teodicéer med forskellige argumentationsstrategier: 1) Privationsteodicéen, hvor det onde slet og ret ses som en mangel på eller fravær af det gode, f.eks repræsenteret ved Plotin og Augustin. 2) Viljesfrihedsteodiceen, hvor onde handlinger stammer fra den handlendes egen vilje, idet man vender sig væk fra det gode, idet Lars Fr. Svendsen her henviser til Augustin, Aquinas og Platon. Flere typer af teodicéer kan således godt optræde hos den samme forfatter. 3) Den ireneiske teodicé (opkaldt efter Irenæus), hvor det onde delvist kommer fra Gud selv og skal tjene som tugtemester for det fejlende menneske. Det onde, lidelserne i verden mv. ses her som en nødvendighed, idet mennesket herigennem tvinges til at stræbe efter perfektibilitet. 4) Helhedsteodiceen tager heroverfor udgangspunkt $i$, at det onde egentlig er det gode, hvis man bare betragter det på den rigtige måde. Platon kan siges at være den første, der har fremsat helhedsargumentet, ligesom der henvises til Boethius, Rousseau, Spinoza, Leibniz, Luther, Goethe, Novalis, foruden atter til Augustin og 
Aquinas m.fl.(!). I et supplerende underafsnit om historien som sekulær teodicé påvises det ydermere, at såvel den historisk funderede fremskridtsoptimisme, der optræder hos Adam Smith, Hegel og Schelling, som kulturpessimismen, der f.eks kommer til udtryk hos Rousseau, Schopenhauer og Nietzsche, over- eller gentager teodicéernes traditionelle borfforklaringer af det ondes realitet. Overfor denne blinde tiltro til Guds eller historiens forsyn sætter Lars Fr. Svendsen Jobs indsigt, der viser os en vej hinsides teodicéen: "Job bliver en eksistentialistisk helt, som ser, at verden ikke er retfærdig, at verden ikke føjer sig efter vores retfærdighedsprincipper" (s.54). Og videre: "Uden sådanne totalitetsforestillinger får det onde plads til at vise sig som ondt (s.55).

Bogens andet hovedafsnit, Ondskabens antropologi, inddeler på lignende overskuelig vis ondskaben i 4 typologier: den dæmoniske, den instrumentelle, den idealistiske og den dumme ondskab.

Den damoniske ondskab giver indtryk af at være selvtilstrækkelig og formålsløs set udefra - vi kender den gennem ofrenes beskrivelser. Den onde tillægges dermed uigennemskuelige og dxmoniske motiver, som $\mathrm{fx}$ i skrækfilm o.lign., men pointen er ifølge Svendsen, at agressoren ikke nødvendigvis har disse motiver. Den dæmoniske ondskab er derfor ikke så udbredt som oftest antaget, snarere er der tale om, at man bevidst vælger et større gode end den ondskab man påfører andre. For sadisten gælder det fx. om at opnå nydelse. Der ligger mao. forståelige motiver bag den overvejende del af ondskaben. Når ondskaben ofte beskrives dæmonisk er det ligesom i middelalderens teodiceer et misforstået forsøg på at bortforklare den. Den dæmoniske ondskab skal først og fremmest forstås instrumentelt.

Den instrumentelle ondskab anlægger det subjektive gode som målestok for sin (onde) handlen, frem for det objektivt gode, som idealisten f.eks. henholder sig til. Den instrumentelle handlen drejer sig dermed om, at man tilsidesætter hensynet til det, som man udmærket ved er objektivt godt, til fordel for opnåelsen af et (inter)subjektivt gode. Der knyttes her til an Kant, idet Svendsen forsøger at modificere dennes abstrakte opfattelse af forholdet mellem godt og ondt: "Hvis jeg vil begå en ond handling, må det være, fordi jeg tror, at denne handling vil bidrage til tilfredsstillelsen af et ønske", således at forstå, at den i sig selv onde handling muliggør opnåelsen af et for den handlende større gode (s.82).

Den idealistiske ondskab opterer overordnet betragtet for en absolut modsætning mellem det objektive gode og onde. Heraf kommer den hyppigt forekommende markante skelnen imellem "dem" og "os" eller mellem de, der opfattes som gode, partifæller eller "troende", og de, der opfattes som onde, modstandere eller "vantro". Ifølge Svendsen er der 
historisk begået ufattelige mængder ondskab pga. (fejl)forestillinger om det onde, idet handlinger, som ret beset er onde, søges retfærdiggøres med henvisning til et absolut ideal. Hekseafbrændinger, korstogene og holocauust er eksempler herpå.

I forbindelse med belysningen af den dumme ondskab knytter Svendsen eksplicit an til Hannah Ahrendts begreb om det ondes banalitet. I Ahrendts analyse af holocausts ondskab finder hun hos Eichmann en form for ubetænksomhed eller ligegyldighed, der er forbundet med det moderne samfunds afpersonaliserende strukturer. Eichmann reflekterer ikke over konsekvenserne af sine handlinger. Det ondes banalitet har at gøre med motivationen for handlingen; "Problemet er at vi sædvanligvis forudsætter en ond vilje, en bestemt intention, for at vi overhovedet skal kunne tale om en forbrydelse" (s.107). Og pointen er ifølge Svendsen, at denne onde vilje er vanskelig at påvise hos naziforbrydere som Eichmann, Höss og Stangel.

Det der optager Svendsen er snarere, at almindelige mennesker er i stand til at udøve de grusomste handlinger, uden at disse mennesker samtidig synes at være berøvet deres fornufts brug. De almindelige tyskere sagde ikke fra - de var ligeglade. Og soldaterne sagde heller ikke fra, hverken generelt eller over for at skulle udføre alvorlige forbrydelser. De følte sig tværtimod som uskyldige ofre, der blot parerede ordre, idet de mente at tjene almenvellet. Svendsen refererer her til undersøgelser, der peger på, at måden, hvorpå mennesker bliver bedt om at handle, er afgørende for om den enkelte benytter sin frie vilje til at sige fra. I den anledning anføres en række faktorer, der gør det "lettere" at handle ondt. Det er bla. afgørende, at der er en vis distance mellem aktør og offer.

Konkluderende på andendelen slår Svendsen fast, at mennesket bør betragtes som både godt og ondt, snarere end som godt eller ondt. Dette implicerer samtidig, at mennesket er frit til at vælge mellem gode og onde handlinger og kan gøres moralsk ansvarlig i de tilfælde, hvor det vælger de onde. Positivt formuleret har individet potentielt, og som hos Kant, i kraft af tænkningen en modkraft mod såvel den dxmoniske, instrumentelle og idealistiske, som den dumme ondskabs uheldige konsekvenser. Dog må Kants sindelagsetik efter Svendsens opfattelse kombineres med en konsekvensetisk sans for, at det onde præcis skal imødegås gennem praksis, som hos Hannah Arendt og i utilitarismen, idet han konkluderer: "I en religiøs sprogdragt kan man med en vis ret sige, at vi alle er syndere. Vi er alle syndere, ikke fordi vi vi har arvet en synd, men fordi, vi alle faktisk har syndet" (s.138).

I det tredje hovedafsnit, Ondskabens problem, gøres der rede for hvorledes ondskaben i den filosofiske tradition har været anledning til en flugt ind $i$ det kontemplative og 
metafysiske, frem for at afføde en aktiv respons. Aristoteles, Marcus Aurelius, Descartes og Wittgenstein ses som eksempler herpå. Det onde er nemlig, som allerede nævnt, et praktisk, ikke et teoretisk problem, fordi al interesse i sidste instans er praktisk. Ydermere har dette konsekvenser for videnskaben forstået som praksis: "Det deskriptive og normative, fakta og værdier, er ikke helt afhængige af hinanden. Normative hensyn påvirker, hvordan vi beskriver en situation, og hvad vi opfatter som "fakta", har konsekvenser for den normative vurdering" (s.145). Der sker i overensstemmelse hermed en perspektivdrejning hen imod det politiske felt som det sted, hvor ondskaben imødegås som et konkret problem. Svendsen tilslutter sig her Stuart Hampshire: "Der er ikke noget mystisk, "subjektivt" eller kulturrelativt $i$ den menneskelige erfarings største onder." (s.159). Vi behøver kort sagt ingen teori for at erkende ondskaben som ondskab.

Bogen afsluttes med et efterord og en epilog omhandlende begivenhederne omkring 11. september. Kort formuleret kan det her siges, at Svendsen forholder sig kritisk både til Bin Ladens terrornetværk og Bush, idet de hver især dæmoniserer hinandens motiver og selv repræsenterer den idealiserende ondskab, hvor den anden (læs: ondskaben) bør bekæmpes med alle midler qua ond. Menneskerettighederne og FN betragtet som disses organisatoriske garant gælder her som de ufravigelige principper hhv. instans, som de implicerede parter må konfronteres med eller holdes fast på. Alligevel må menneskerettighederne fraviges i specifikke undtagelsestilfælde, anføres det, nemlig når statens $o g$ individers sikkerhed er truet, men NB! ikke i generel henseende. Den store vanskelighed består med andre ord ifølge forfatteren i nærmere bestemt at afgøre, hvornår der er tale om hvad.

Kritik: Ondskabens filosofi er skrevet i et klart sprog, og glimrer ved sin detaljerigdom og grundighed. Ligeledes imponeres man som læser af dens analytiske styrker, f.eks hvad angår typologiseringen af ondskaben og teodicéopfattelserne. En anden indlysende styrke ved bogen er, at den ægger til diskussion, hvilket gerne skulle fremgå af det efterfølgende.

Det overordnede sigte med bogen er at fokusere på enkeltmenneskets og nationernes forpligtelse til at bekæmpe det onde i verden. Denne opfordring kan siges at være baseret på en filosofisk reaktualisering af Kants kategoriske imperativ og Benthams utilitarisme, idet de to søges kombineret eller sammentænkt. En rekapitulation heraf kunne tage sig således ud: "Du skal handle således, at maximen for din handling bliver at mindske det onde mest muligt for det størst mulige antal mennesker". Det bemærkes her, at der bogen igennem sættes lighedstegn mellem lidelsen som påført og ondskaben per se. Ved 
at rette fokus på lidelsen som påført mener Svendsen, at ondskaben bliver mere konkret og dermed mere håndterbar. Men spørgsmålet er alligevel, om han lykkes med sin revision af Kants abstrakte tilgang til moralen. Til forskel fra Kant ønsker han fremdeles at fundere moralen $i$ en situationisme (pragmatisme), idet spørgsmålet om godt og ondt altid indgår i en diskursiv og social praksis. Samtidig hævder Svendsen imidlertid, at man stadig bør gøre universelle principper gældende, såsom folkeretten og menneskerettighederne. Bin Laden og Bush er her lige gode om at fornægte begge principper, idet de hver især ser modparten som representant for den dæmoniske ondskab. Heroverfor byder bogen sig intentionelt til som et normativt bud på, hvordan tingene efter Svendsens opfattelse burde forholde sig. Man må dog spørge, om ikke den gennemgående sammenblanding af det deskriptive og det normative niveau i analysen, jvf. ovenstående referat, gør analyserne mindre præcise end forfatteren selv hævder og ønsker. På det deskriptive niveau kan man således hævde, at der er tale om en temmelig naiv fremstilling af, hvad det egentlig er politik og magt handler om. Hermed kommer værket paradoksalt nok let til selv at fremtræde som det, det netop ikke vil være, nemlig en bortforklaring af lidelsen qua grum realitet. Det tyvende århundredes filosofi og sociologi vidner $i$ hvert fald om andre tilgange til forholdet mellem magt og politik, som byder sig til eller lader sig tænke. Eller sagt på anden vis: Måske er der en god grund til, at Kant, som Svendsen har et til tider forstyrrende faderopgør med, forbliver i det abstrakte i sin bestemmelse af moralen, dvs. i kraft af sin forståelse for det politiske felt som hjemsted for de hypotetiske imperativer. Ovenstående kategoriske imperativ, der forudsættes værket igennem, kan fremdeles til enhver tid afvises, idet der reelt er tale om et hypotetisk sådant. Måske kunne man forsigtigt foreslå Svendsen at opgive det i bogen forudsatte moralsk ophøjede ståsted, for i stedet at formidle dens budskab som en - i givet fald - særdeles anvendelig social klogskabslære. Således forstået lod Ondskabens filosofi sig læse som en håndbog $\mathrm{i}$ moderne politisk takt og tone.

I tråd hermed kunne man pege på, at det principielt må være arbitrært eller genstand for (diskursiv) konfliktualitet individer og nationer imellem, hvorvidt eller hvornår de abstrakte principper, som Svendsen henholder sig til, overhovedet lader sig applicere på de konkrete begivenheder eller situationer - noget en række muslimske og afrikanske stater sikkert kunne skrive under på. Går vi lidt videre i samme retning er det ligeledes i høj grad relevant, som Svendsen selv er inde på det sine steder, hvorledes man - udefra betragtet - $i$ sidste ende konkret skelner mellem hhv. instrumentel og den idealistiske ondskab på den ene og så den militante hu- 
manisme eller svage konsekvensetik, som der vedvarende plæderes for, på den anden side. Alle accepterer de jo det onde for at opnå det gode, og spørgsmålet om den enkelte nations eller det enkelte individs motiver; i.e. om det primært er dækkelsen af egne behov, som man vil til livs eller det gode samfund, man vil realisere, er langtfra så let at besvare som Svendsen lader til at mene. Og det samme gælder placeringen af ansvar for påførelsen af de konkrete lidelser i verden, hvor årsagskæderne ofte fortaber sig i det politiske livs systemiske tåger, ligesom man jo altid - og tilmed med socialvidenskaben $i$ baghånden kan undskylde sig med kun at være en lille brik i et større spil. Her hjælper det med andre ord fedt at henvise til, at man burde have vidst bedre, hvis man havde tænkt sig om eller brugt sin fornuft. Særligt når man betænker, at Svendsen selv henviser til, at man præcis ikke kan overskue konsekvenserne af politiske handlinger og beslutninger. Af en filosofi at være, der vil efterlade teorien for at overgå til praksis, kunne man derfor hævde, at den selv arbejder med en temmelig teoretisk eller spekulativ skelnen mellem dumhedens, den instrumentelle eller idealistiske ondskab på den ene og så den militante humanisme på den anden side.

I sidste ende strander diskussionen efter alt at dømme på det antropologiske grundsynspunkt, der er værkets forudsætning. Det forudsættes således vedvarende, at refleksionen eller fornuften kan tjene som brugbart remedie ift. den idealistiske, dumme og instrumentelle ondskabs uheldige konsekvenser. Men kan den nu det? Er vore egne motiver så let gennemskuelige for os selv og andre, som det bestandig fremhæves? Er vi virkelig i alt væsentligt frit handlende og moralsk ansvarlige individer, som det hrvdes, og kan man desuden uden videre slutte fra individet og til det universelt menneskelige, idet man missionerende pålægger individet et medansvar overfor lidelsen i verden? Enhver kan her svare for sig selv, men helt irrelevante spørgsmål er det vel ikke, om end de alle som ét besvares bekræftende i Ondskabens filosofi? Således kunne man i stedet fremhæve eller søge at belyse de menneskelige motivers og handlingers uigennemskuelighed eller modsætningsfyldte gådefuldhed. Svendsen er da også inde på denne tilsyneladende uigennemtrængelighed, men gør ellers, som nævnt, direkte en dyd ud af at holde analyserne på et overfladisk niveau.

$\mathrm{Nu}$ må det retfærdigvis nævnes, at der i Ondskabens filosofi netop tages afstand fra enhver essentialisme, bl.a ved forsøgsvis at føre spørgsmålet om det onde over i en konkret praktisk sfære. Således kommer pragmatismen forfatteren til hiælp og undsætning, idet den tjener som modvægt mod det abstrakt filosofiske, mens omvendt det abstrakt-universelle tjener til at undgå situationismens relativistiske 
snarer. Denne manøvre er i bedste fald snedigt udtænkt, men i værste fald udtryk for filosofisk eklekticisme (såfremt man altså insisterer på at præsentere sin egen diskurs som konsistent filosofi, hvilket Svendsen tydeligvis gør!), og tillige vanskelig at gennemskue for den ubefarne læser, som måtte efterlyse anvendelig tænkning fra filosoffernes side. Men måske består storheden ved Ondskabens filosofi netop i, at den afspejler de p.t. forhåndenværende muligheder for at meddele sig filosofisk, dvs. hvis man vil have sit budskab hørt. Det kan så at sige forekomme "nødvendigt" at sammenkokkerere en smagfuld gryderet med dertilhørende afslappet nedbrydning af traditionelle skel de filosofiske skoler og analytiske bestemmelser imellem, hvis man som filosof vil trænge igennem den almindelige informationsstrøm.

Konkluderende må det siges, at Ondskabens filosofi helgarderer sine udsagn med forbehold, som den straks bagefter fraskriver sig. Den er belærende og påståelig til det uudholdelige, og kunne derfor - til trods for sin påstand om det modsatte - lige så godt have heddet "Godhedens filosofi". Den er altfavnende til det ubehagelige (herunder øjensynlig internetvirusbefængt - hvorfor skal Gud og hver mand nævnes?). Den er højstemt og udtaler sig bramfrit på hele menneskehedens vegne $\mathrm{i}$ tide og utide, men den er samtidig ydmyg over for egne resultater. Den pend- ler, som anført, ubesværet omend ikke uproblematisk mellem et deskriptivt og et normativt niveau. Har Svendsen aldrig hørt om Nietzsches' "Jenseits von Gut und Böse", for nu at henvise til en af de få, som der ikke henvises ret meget til undervejs? $\mathrm{Og}$ hvad får man f.eks. ud af at blive fortalt, at Osama Bin Laden er ond, og at Bush også er det? Men denne lange række af spørgsmål, som bogen her har foranlediget, er det måske netop dens fortjeneste og styrke at forsøge at overskride - den tilbyder sig jo som et stærkt bud på en individuel og politisk moral i vores tid. Imidlertid består også dens næsten middelalderlige overmod heri.

\section{Bjarne Vind Sorensen og Jens Viggo} Nielsen

\section{Samtaler med Giddens}

Samtaler med Anthony Giddens, at forstå moderniteten, Hans Reitzels forlag 2002, 236 sider, $225 \mathrm{kr}$.

Den engelske sociolog Anthony Giddens er efterhånden godt introduceret på dansk. Hans Reitzels Forlag har udgivet flere af hans værker samt en introduktion til Giddens' forfatterskab ved Lars Bo Kaspersen.

Den nye publikation - Samtaler med Anthony Giddens - består af en introducerende indledning ved 